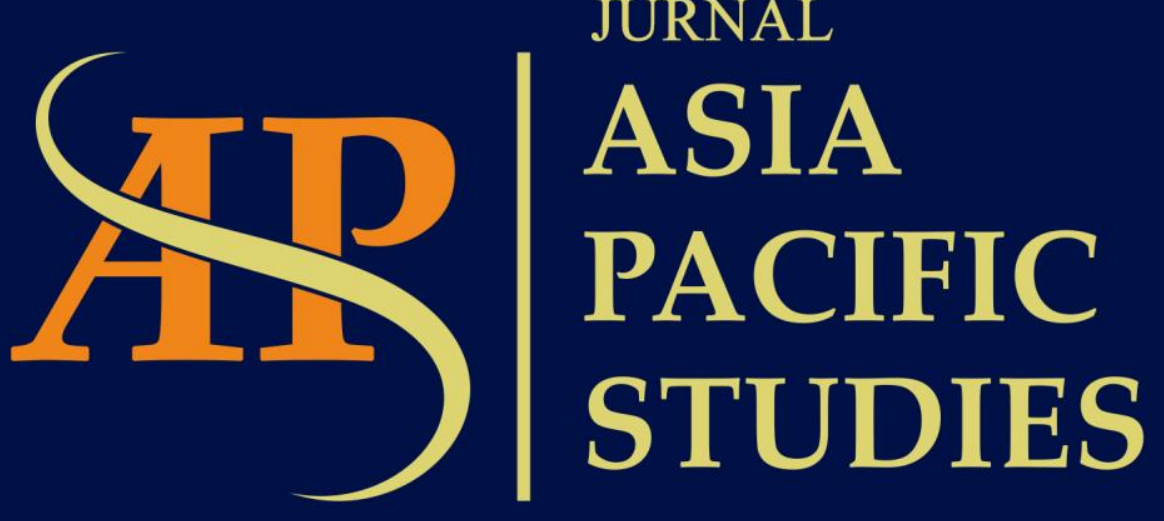

Journal of International Relations Study Program Faculty of Social and Political Sciences Universitas Kristen Indonesia

Volume 2 | Number 1 | January - June 2018 


\title{
Improving Free Trade Agreement (FTA) Between Indonesia-European Union (EU) Through Comprehensive Economic Partnership Agreement (CEPA)
}

\author{
Hendra Manurung \\ International Relations, President University, Jl Ki Hajar Dewantara Cikarang, West Java 17550 \\ h_manurung2002@president.ac.id
}

\begin{abstract}
This study aims to analyze the free trade agreement (FTA) between Indonesia and the European Union (EU) through Comprehensive Economic Partnership Agreement (CEPA). Suppose it improves economic relations while creating benefits for both. In 2012, Indonesia and the EU began negotiation on the CEPA. The CEPA has been presented as having the ability to help both parties take full advantage of unexploited economic relations. The CEPA is a comprehensive agreement discussing various aspects of economic relations. It is beyond being a simple agreement for removing trade barriers. The liberalization of international trade in goods remains to be an important aspect of the CEPA, investment promotion and facilitation, the improvement of trade in services, and the creation of improved competition policy practices would promote greater economic relations. CEPA contributes Indonesia economics development, i.e.: to promote increased trade between Indonesia and the EU. It focuses on trade liberalization boosting the trade relations intensity by lowering trade barrier and by facilitating trade; to boost trade and investments in services; to enhance technological advance and skills transfer in the goods, services and investment. A free trade agreement between the EU and Indonesia provides a stable, balanced, and long-term framework to challenge economics integration.
\end{abstract}

Keywords: the EU, Indonesia, CEPA, liberalization, economics integration

\begin{abstract}
Abstrak
Penelitian ini bertujuan untuk menjelaskan potensi efek dari Perjanjian Kemitraan Ekonomi Komprehensif (CEPA) mengenai perdagangan barang dan jasa antara Uni Eropa dan Indonesia, dan dalam penanganan isu-isu utama yang dianggap dapat menghambat perundingan CEPA. Seharusnya kesepakatan antara Uni Eropa dan Indonesia akan memperbaiki dinamika hubungan ekonomi yang ada, sekaligus menciptakan berbagai manfaat bagi keduanya. Indonesia dan Uni Eropa mulai melakukan negosiasi persiapan CEPA di tahun 2012. CEPA digambarkan memampukan kedua belah pihak memanfaatkan sepenuhnya hubungan ekonomi yang tidak saling mengeksploitasi hubungan ekonomi antara Uni Eropa dan Indonesia. CEPA diharapkan menjadi kesepakatan komprehensif dalam membahas berbagai aspek hubungan ekonomi tersebut, dan karenanya telah melampaui kesepakatan sederhana untuk penghapusan hambatan perdagangan. Sementara liberalisasi perdagangan internasional barang tetap sebagai aspek penting CEPA, promosi investasi dan fasilitasi, peningkatan perdagangan jasa, dan penciptaan praktik kebijakan persaingan yang lebih baik dalam promosi hubungan ekonomi yang lebih luas. Indonesia berharap adanya tiga kontribusi utama dari CEPA, yaitu: Mempromosikan perdagangan Indonesia dan Uni Eropa. Fokus kesepakatan pada liberalisasi perdagangan dapat meningkatkan intensitas hubungan perdagangan dengan menurunkan berbagai hambatan dagang, dan dengan memfasilitasi perdagangan; meningkatkan liberalisasi perdagangan dan investasi jasa; meningkatkan kemajuan teknologi dan keterampilan di sektor barang, jasa dan investasi. Adanya perjanjian perdagangan bebas (FTA) antara Uni Eropa dan Indonesia memberikan kerangka kerjasama ekonomi perdagangan yang stabil, seimbang, dan berjangka panjang dalam peningkatan hubungan perdagangan dan integrasi ekonomi antar kawasan.
\end{abstract}

Kata kunci: Uni Eropa, Indonesia, Perjanjian Kemitraan Ekonomi Komprehensif(CEPA), integrasi ekonomi 


\section{Background}

The relation between the European countries and Indonesia has developed since 1949. The European Union (EU) - Indonesia relations were led by the EU-ASEAN partnership in 1972 when the European Economic Community (EEC) became ASEAN's first formal dialogue partner (Lim 2012). Follow with closer relations between the two regions are expanding, developing progressively on the economic, political and cultural fronts. Dialogue between the two regions has been enhanced with numerous technical level meetings and bi-annual Ministerial meetings. Therefore, whereas in the past, much of the Europe-Southeast Asia relationship has focused on Southeast Asian development, the focus of cooperation has transformed to an emphasis on diplomacy, where the two sides discuses regional and international problems, and finally to a new emphasis on non-traditional risks and regional integration support (Lim 2012).

This article focuses on the improvement of free trade agreement by the European Union (EU) and Indonesia through comprehensive economic partnership agreement framework.

ASEAN helped maintaining regional security and peaceful environment in Southeast Asia and lowered barriers to travel and trade, supporting the region's economies in taking off (Acharya 1995). That growth has lifted millions of people out of poverty and has allowed many more achieve their dreams.

Today, interdependence is global, complex, and broad based, comprising not only trade but also finance and production networks. Furthermore, interdependence today is not just an economic phenomenon. The various issue areas that are central to global governance today, such as climate change, refugee flows, pandemics, and human rights abuses are precisely what add scope, depth, and complexity to the nature of global interdependence (Acharya 2016).

At least there are 4 (four) advantages for Indonesia trade liberalization, i.e.: tremendous natural resources; a burgeoning domestic consumer class; strong democratic political leadership; and a stable financial system. Domestically, the national risks are also real, such as: a partially reformed legal and regulatory economics environment, improving national infrastructure, rigidities of systemic labor market, and rampant bureaucracy corruption.

Therefore in terms of attracting foreign direct investment (FDI), despite its remarkable potential as an investment destination, in recent years Indonesia has fallen dramatically off the blistering pace set by its economic competitors. As an essential element of any strategy to overcome the structural challenges that accompany economic transformations, FDI provides capital, technology transfers and productivity gains to host countries. If targeted within the framework of a wider strategy, the successful attraction of FDI can bring immense benefits to the host's domestic economy.

Despite contrary popularly held conceptions about FDI, empirical research demonstrates that FDI has brought job growth to many developing countries including China, Mexico and several countries in Central Europe. The importance of a coherent FDI strategy cannot be overemphasized, as FDI is by nature finite and most effective when channeled to sectors with specific competitive advantages and when oriented towards specific development goals. Investment promotion intermediaries (IPIs), when successfully empowered to guide FDI strategy and promotion, can influence foreign investor perceptions about a given investment destination. 
In 1990s', the destruction of the Cold War bipolar structure and the emergence of regional systems turned analysts' interests away from the geo-strategic approaches of the superpowers toward regional developments. In this era the Association of Southeast Asian Nations (ASEAN, 1967 to 2018) developed from a Cold War alliance into a regional organization emphasizing its originating idea of gathering all Southeast Asian countries together under the same co-operational organization (Palmujoki 2001). Rapid economic growth and increasing political self-confidence among the ASEAN members also characterize this period (Khong 2005). While in 1970s and 1980s the growing economic might of ASEAN countries highlighted the distinctive character of Southeast Asian regionalism, the Asian economic crisis in 1997 to 1998 (Rüland 2000). It also due to Asia-Pacific economic reconstruction results and political change systems, forced the rethinking of many assumptions behind Southeast Asian regional development (Palmujoki 2001).

The EU-ASEAN relations refer to bilateral foreign relations between the two organizations, the European Union (EU) and the Association of Southeast Asian Nations (ASEAN). EU and ASEAN have been interacting with each other on the economic, trade and political levels (Haas 2004). Bilateral cooperation was continuously expanded and eventually the EU Delegation to Indonesia was opened in 1988. Economic and political dialogue between Indonesia and the EU takes the form of regular Senior Officials Meetings. In 2000 relations were further reinforced with the release of the European Commission's communication "Developing Closer Relations between Indonesia and the EU" (Lim 2012).

In Southeast Asia region, Indonesia is best suited to become a strategic pivot. With a population of 265 million (BPS 2018), Indonesia is $3^{\text {rd }}$ world democratic state after US and India, also the world's populous Islam state. Indonesia foreign policy must be based on the down to earth diplomacy and strengthening public diplomacy, which can be implemented with Indonesia people interests. Southeast Asia is one of the fastest-growing, most dynamic regions in the world.

Indonesia's working population has reached 127.07 million in February 2018. It was up by 2.53 million compared to the same period of 2017, which has been recorded at 124.54 million (BPS 2018). Of the total 127.07 million working population, 87.08 million are full-time employees, 30.29 million are part-time employees, and 9.7 million are under-employed. There some 53.09 million people work in the formal sector, and 73.98 million works in the informal sector.

While, industrial sectors recorded an increased percentage in working population are accommodation and other services, food and beverages industry, and processing industry. Followed by agriculture, construction, and education services have recorded a decline in the number of workers (BPS 2018). Still, agriculture is the largest contribution to jobs structure, with 30.46 percent of the working population; trade, with 18.53 percent; and processing industry, with 14.11 percent (BPS 2018). The average labor wage is Rp2.65 million per month in 2018.

For almost twenty five years, the European Community Cooperation Agreement with the Association of South East Asian Nations (ASEAN) is formalized in 1980. On this basis, economic and political discussions have been held regularly. Bilateral dialogues between the EU and Indonesia have included periodic reviews of political, economic and cooperation issues in Senior Official Meetings (Severino 2005).

A Framework Agreement on Comprehensive Partnership and Co-operation was signed on 9 November 2009 and entered into force on 1 May 2014 (Indonesia Ministry of Trade 2016). The Agreement provides the basis for holding regular political dialogue and sector cooperation and takes bilateral relations to a higher level. The Agreement provides the legal 
framework to engage and cooperate across a wide spectrum of policy fields, including human rights, political dialogue, and trade. A Free Trade Agreement develops a key aspect of overall bilateral relation between the EU and Indonesia (the EU Delegation to Indonesia \& Brunei Darussalam 2016).

Indonesia benefits from trade preferences granted by the EU Generalized Scheme of Preferences (GSP), under which about 30 percent of total imports from Indonesia enjoyed lower duties (Indonesia Ministry of Trade 2016).

The EU Generalized Scheme of Preferences (EU-GSP) since 1971 has assisted developing countries in their efforts to reduce poverty, promote good governance and sustainable development. By providing preferential access to the EU market, the GSP helps developing countries in generating additional revenue through international trade. Regulation Number 978/2012 of the European Parliament and the Council of 25 October 2012 on applying a scheme of generalized tariff preferences or the GSP Regulation is the legal framework for the GSP. The scheme is in line with WTO law, having been introduced under the so-called "Enabling Clause", which allows an exception to the WTO "Most Favored Nation (MFN)" principle (EU Commission 2016).

In April 2016 to further deepen the EU Indonesia trade and investment relations, negotiations for an EU-Indonesia free trade agreement were launched on 18 July 2016 (the EU Delegation to Indonesia \& Brunei Darussalam 2016). Indonesia government ambition is to conclude a free trade agreement that able to facilitate trade and investments and covers a broad range of issues, including tariffs, non-tariff barriers to trade, trade in services and investment, trade aspects of public procurement, competition rules, intellectual property rights as well as sustainable development. Indonesia is one of 30 developing countries which benefits from EU preferential market access arrangement (EU Commission 2016).

On 21 September 2016, Iman Pambagyo, Director General for International Trade Negotiations stated that, 'For Indonesia, principally and in general, Indonesia proposal which is pursuing national interests mostly accommodated by the EU. It is positive for Indonesia (Indonesia Ministry of Trade 2016)

A Free Trade Agreement develops a key aspect of the overall relationship between the EU and Indonesia which is framed by the Partnership and Cooperation Agreement which entered into force on 1 May 2014 (the EU Delegation to Indonesia \& Brunei Darussalam 2016). In Brussels, on 18 July 2016, EU Trade Commissioner Cecilia Malmström and Indonesian Minister of Trade Thomas Lembong agreed to officially launch the negotiations for a Comprehensive Economic Partnership Agreement (CEPA) between the EU and Indonesia with the aim to deepen and strengthen a key aspect of the bilateral relationship.

The announcement follows decision by the EU Council to give the green light to the European Commission to open negotiations for Indonesia based on intense preparatory work (the EU Delegation to Indonesia \& Brunei Darussalam 2016). The EU Commissioner Malmström and Minister Lembong jointly declared: "The EU and Indonesia represent a huge market of 750 million consumers. These negotiations are substance to unleash synergies between our economies. Our trade relationship has enormous untapped potential. The EU as the world's largest trading block and Indonesia as the largest player in the dynamic region of Southeast Asia region have lots to gain from a deeper trade and investment relation. The Agreement holds a promise of new great opportunities for businesses and people in our countries. That is why we engage today with a firm resolve to make these talks succeed" (the EU Delegation to Indonesia \& Brunei Darussalam 2016).

Thus, both sides agreed to negotiate an ambitious agreement that facilitates trade and investments and covers a broad range of issues, including customs duties and other barriers to 
trade, services and investment, access to public procurement markets, as well as competition rules and protection of intellectual property rights. The agreement also includes a comprehensive chapter aiming to ensure that closer economic relations between the EU and Indonesia go hand in hand with environmental protection and social development (the EU Delegation to Indonesia \& Brunei Darussalam 2016).

\section{Regional Economic Integration}

Regional integration is the process by which two or more nation-states agree to cooperate and work closely together to achieve peace, stability and wealth. Integration usually involves one or more written agreements that describe the areas of cooperation in detail, as well as some coordinating bodies representing the countries involved.

This cooperation usually begins with economic integration and as it continues, comes to include political integration. The process in which two or more states in a broadly defined geographic area reduce a range of trade barriers to advance or protect a set of economic goals defined as economic integration.

Regional economic integration is expected to promote foreign direct investment through reduction in trade cost, market enlargement and improving policy credibility. The term trade cost is used in a broader sense to encompass all costs that are incurred in conducting international trade and include transport costs, tariffs, and other transaction costs.

Obviously there are a myriad of other factors which influence FDI location decisions. These include political and economic stability, the thrust of economic and investment policies, and the quality and availability of resources and infrastructure. Thus in analytical terms, the issues surrounding the impact of regional economic integration initiatives on FDI are indeed complex, and depend on the type of investment involved.

The institutional arrangements designed to facilitate the free flow of goods and services and to coordinate foreign economic policies between countries in the same geographic region. Economic regionalism can be viewed as a conscious attempt to manage the opportunities and constraints created by the dramatic increase in international economic ties since the end of World War II. Economic regionalism examples include free-trade areas, customs unions, common markets, and economic unions. Several schemes for regional economic integration were established in Europe in the decades following World War II, including the European Coal and Steel Community in 1952. It developed as the embryo of European Union. It established as economic regionalism.

The level of integration involved in an economic regionalist varies enormously from loose association to a sophisticated, deeply integrated, and trans-nationalized economic space. It is in its political dimension that economic integration differs from the broader idea of regionalism in general.

Although economic decisions go directly to the intrinsically political question of resource allocation, an economic region can be deployed as a technocratic tool by the participating government to advance a clearly defined and limited economic agenda without requiring more than minimal political alignment or erosion of formal state sovereignty. The unifying factor in the different forms of economic regionalism is thus the desire by the participating states to use a wider, trans-nationalized sense of space to advance national economic interests.

A major crisis hit the economies of Southeast Asia in mid-1997 to 1998. Its effects were severe, particularly on the countries of the Association of Southeast Asian Nations 
(ASEAN), many of whose currencies suffered marked devaluations. ASEAN was founded on 8 August 1967 by Indonesia, Malaysia, the Philippines, Singapore and Thailand. Brunei joined in 1984, Vietnam in July 1995, and Laos and Myanmar in July 1997.

Prior to the crisis, many of these countries had been experiencing prolonged periods of economic growth: indeed four of them had been identified as high-performing Asian economies or HPAEs by the World Bank in its assessment of the 'East Asian Miracle' (World Bank 1993). Those countries are Singapore, Indonesia, Malaysia and Thailand. While the other four HPAEs were Japan, Hong Kong, the Republic of Korea, and Taiwan.

The Western Europe, and in particular the European Union (EU) was starting to show increasing interest to some of developed Asian countries ((Roger Strange 2000). In 1994, the European Commission published a strategy document calling for stronger ties with the Asian economies or the Commission of the European Communities in 1994. The Asia-Europe Meetings (ASEM) was introduced that the first of which took place in Bangkok in 1996, and the second in London in 1998. The ASEAN markets were becoming increasingly important destinations for EU exports, and more important locations for EU foreign direct investment (Roger Strange 2000).

The economic integration of several countries or states may take a variety of forms. The term covers preferential tariffs, free-trade associations, customs unions, common markets, economic unions, and full economic integration. The parties to a system of preferential tariffs levy lower rates of duty on imports from one another than they do on imports from third countries. For example, Indonesia and its ASEAN member-states operated a system of reciprocal tariff preferences after 2003 ASEAN Free Trade Agreement signed. In free-trade associations no duty is levied on imports from other member states, but different rates of duty may be charged by each member on its national economic interests.

\section{Regional Trade \& Investment}

The idea of regional free trade has been around since at least 1966, when Japanese economist Kiyoshi Kojima advocated a Pacific Free Trade Agreement (PFTA). The actual talks began with the Asia Pacific Economic Cooperation (APEC) forum, which was created in Canberra (Australia) in January 1989. Practical measures ensued during the November 1994 meeting in Bogor, Indonesia, when APEC leaders opted for free and open trade and investment in the Asia Pacific (Manurung 2016).

Southeast Asian countries are unique among the major geographic regions in the world for its dynamics level of intraregional trade. The conventional wisdom based on standard trade theory holds that there is little room for fostering intra-regional trade through collective action given the similarities of these countries in terms of resource endowments. However, the proponents of regional economic integration argue that the static comparative advantage argument based on existing patterns of economic integration should not be treated as a guide to policy, and there is ample room for creating economic complementariness through further trade and investment policy reforms. By referring to the on-going process of global production sharing through international production fragmentation and giving examples from the experiences of the East Asian economies in reaping gains from this new form of international exchange, they argue that there is potential for integrating production processes among countries by promoting vertical of efficiency seeking foreign direct investment (Dosani 2010, RIS 2008). 
Indonesia strengthened existing and future cooperation within the framework of the Indonesia - European Union Partnership and Cooperation Agreement (PCA), which ratified by both Indonesia and Germany respectively on 24 February 2012 and 2 May 2012 (Indonesia MOFA 2012). Through Jakarta Declaration on 10 July 2012 signaled Indonesia efforts to have the Agreement ratified by all member states of the EU with a view to ensuring its entry into force and implementation (Indonesia MOFA 2012). It puts relations between the two countries on a new broader footing and will pave the way for strategic cooperation in the economic sector in particular.

However, still it's debatable whether the uneasiness many European citizens feel towards national and EU or European policies could be overcome simply by strengthening national sovereignty and dismantling the EU or even pan-European bodies and institutions (Dinan 2005). Many of the causes have an authentic national origin, such as a fear of the future due to an increase in social inequality, environmental degradation or threats to public safety and security, regardless of whether they are real or only felt. Slogans such as "More Europe" or "Less Europe" are, therefore, not suitable for getting to the bottom of the causes.

In fact, a sensible combination of national and the EU or the European measures is needed to be able to restore the confidence of European citizens in their joint project, for overall prosperity and safety. National and supranational measures are also necessary to secure European common social model, the European welfare state (Haas 2004).

Only a strong EU and or Europe can protect its citizens from the consequences of unrestrained globalization. Hence, member states have to ensure social justice within their own borders. Such a deliverables have no alternative.

The call for more autonomy and civic participation requires not only national but also allEuropean action. Democratic deficit have not only been unveiled in the EU, whose institutions certainly need a surge of democratic ideas and practices, but also in many of the EU 28 member states. The limitations of a dismal representative democracy come to light when they only partially and incompletely portray the will of the citizenry.

If it is possible to adopt these kinds of measure in a targeted manner and fulfill the true needs and concerns of the citizens accordingly, then it is also possible and manageable to continue the promised work of the EU integration in the best interest of European family of peoples (Haas 2004). Of course, it will have to take national particularities, diversities, which make up the firm characteristics of Europe, into account to a much higher extent then it is the case now. A reinvigorated EU will also have to exist under the banner of this cultural diversity and it can remain the Union of the four fundamental freedoms and all other civilization accomplishments, which defined its historical cause and will define the lives of its citizens today (Dinan 2005).

Thus, in analyzing the impact of regional economic integration on the FDI-trade nexus, it is important to distinguish between horizontal investment (or market-seeking) FDI or HFDI and vertical (efficiency-seeking) or VFDI. HFDI takes place when a multinational enterprise (MNE) produces the same goods and services in order to avoid trade costs of exporting goods from one country another, while retaining its firm specific advantages in production.

By contrast, VFDI takes place when a MNE geographically fragments the production process (value chain) of a given product into stages, in order to take advantage of locationspecific advantages such as lower factor prices in other countries.

Moreover, VFDI is more likely to occur for firms with production processes that can be easily fragmented into several stages characterized by different factor intensities and between countries with different factor endowments. In each case, the MNE faces trade-offs 
in its investment decision: avoiding trade cost through HFDI implies foregoing economies of scale, as production is distributed across several plants located in different host countries, whereas VFDI involves costs of coordinating fragmented activities in several locations ('services link cost', a la Jones and Kierzkowski 2000). Some of the factors that are important in these trade-offs are firm or industry specific (e.g. the importance of economies of scale), and some depends on country characteristics such as market size, factor price differences, and various aspect of the trade and investment policy region. VFDI is predicted to occur when factor cost savings are large relative to the costs of coordinating fragmented activities in several locations (Navareti and Venables 2005).

In the context of regional economic integration, HFDI can take two forms, tariff-jumping investment or investment triggered purely by tariff preferences, and investment driven by the market enlargement effect. Tariff-jumping investment would contribute to trade diversion, shifting the location of production from a low-cost source of supply outside the region to a higher-cost source in a member country.

The attractiveness of the region for tariff-jumping investment depends on the magnitude of the "margin of preference", the difference between the preference tariff among the member countries and the tariff applicable to trade with third parties. Differences in members' tariffs may be important in procuring low-cost imported inputs, which could influence the location of investment in relatively low tariff countries in the region from third countries as well as from high tariff countries within the region. This influence would be magnified if there are significant differences among member countries in non-tariff barriers to third country trade.

In the early literature on the investment effect of regional economic integration, it was generally believed that, apart from the contemporaneous influence of the existing or initial preference margins, the formation of a regional trading agreement (RTA) can impact on investment decisions of the tariff-jumping variety by creating a (perceived or real) threat of protection for extra-regional trade. The simple point here was that the creation of a wider regional market may foster a more projectionist approach towards extra-regional trade. There is, in fact, evidence that one of the principal factors behind the massive increase FDI inflows to countries in the EC since the late 1980s was the concern that the single market would be heavily protectionist: that the existing structure of protection with national quotas would give way to EC-wide quotas and a tougher trade regime (Balasubramanyam and Greenaway 1993). However this postulate is of limited relevance for analyzing the investment effects of modern RTAs because most if not all partners to RTAs pursue regional trade liberalization as an integral part of their commitment to unilateral and multilateral of WTO-based trade liberalization.

HFDI driven by the market enlargement effect has the potential to promote intra-regional trade. The removal of tariff barriers on intra-regional trade leads to an increase in the size of the domestic market, enabling plants that are large enough to exploit economies of scale to be built. The market enlargement effect would be greater if the member nations have similar income levels and demand structures, but diverse preferences for varieties of goods or a condition which is generally met by developed, rather than developing, countries. The formation of a RTA could allow producers to exchange scale economies in the provision of differentiated goods. In an enlarged market, economies of scale may be achieved through the construction of large plants that produce a single product economies of scale in the traditional sense, through the reduction in the number of product varieties in individual plants or horizontal specialization, and through the manufacture of parts, components, and accessories of a particular product in separate locations or vertical specialization. The first type of scale economy is particularly important in heavy industry, such as steel, chemicals, petroleum refining and pulp and paper.

It is important to note that, even in a context of significant and continuous decline in the margin of preference as part of the ongoing multilateral trade liberalization process, the formation of a RTA can have a significant impact on FDI inflows. For the same reasons 
emphasized in the traditional literature on economic integration, such as scale and scope economies, spill-over externalities etc., liberalization among neighbors would expand markets and thus induce better utilization of resources, creating incentives for new investments. Put another way, if transport and transaction costs associated with trade with the rest of the world are substantial, expansion of the market following the formation of a RTA could be more important for the exploitation of scale economies compared to integration with the global economy.

\section{Partnership \& Cooperation Agreement}

Since 2007, Indonesia has made steady economic progress with an average annual real GDP growth rate of 5.9\%. GDP per capita almost doubled to almost US $\$ 3,500$ and the poverty incidence declined from a post-crisis peak of $24 \%$ to $12.4 \%$ in 2011 (WTO 2013). These and other solid fundamentals provided good underlying support in the face of the 2008-2009 global recession. Looking ahead, the government's 2011 Master Plan for the Acceleration and Expansion of Economic Development 2011-2025 recognizes that higher and sustainable economic expansion requires that the country diversify sources of growth, accelerate infrastructure development and close the development gap between eastern and western regions. Real GDP has been forecast by the World Bank to grow by $6.1 \%$ in 2012 , rising slightly to $6.3 \%$ in 2013, assuming continued strong consumption and investment growth, supported by a recovery in exports (WTO 2013).

Obviously, Indonesia has taken steps to improve its business environment, which is reflected in improvements in its rankings in various global indicators. In addition to positive assessments of Indonesia's macroeconomic climate and FDI regime, some notable reforms include the launch of the Indonesia National Single Window to facilitate online processing of trade and licensing activities and the development of initiatives to improve governance.

State-owned enterprises (SOEs) continue to play a key role in Indonesia's economy, estimated to account for around $40 \%$ of Indonesia's GDP. There has not been any significant privatization activity over the review period. However, the Government has partially divested itself of some of its ownership shares in various industries, including: cement, telecommunications, mining, energy, pharmaceuticals, construction, highways, steel, manufacturing, airlines and banks. An SOE monopoly on the importation of alcoholic beverages was terminated in 2010.

Trade remains limited as a share of economic output, with merchandise exports accounting for between $21 \%$ and $26 \%$ of GDP during the review period and imports for between $15 \%$ and $18.5 \%$ of GDP (WTO 2013). Indonesia continues to trade more energy-related products (fuels) than any other product category on both the import and export sides. A number of measures, including export restrictions and taxes on raw resources, tighter import licensing requirements, point of entry restrictions on imports, ownership limitations on banks and certain divestment requirements for foreign mining companies have recently raised concerns about the direction of trade and investment policy-making. In this regard, the central government authorities consider that domestic industrial policy considerations, aimed, inter-alia, at developing local industries and moving up the value chain, should be balanced with maintaining an open foreign trade and investment regime in order to ensure that Indonesia's external commitments continue to be fully respected.

Indonesia provides at least MFN treatment to all WTO Members. In order to improve trade and investment policies, Indonesia has enacted new laws relating, inter alia, to investment, its SPS regime, and export financing, special economic zones as well as in agriculture, fisheries, shipping, mineral and coal mining and tourism. Indonesia is continuing to strengthen its economic ties with countries in the region, both bilaterally and through its participation in 
ASEAN. Under ASEAN, which is working towards achieving an ASEAN Community by 2015, new goods and investment agreements have recently entered into force.

Indonesia's medium-term trade policy objectives are to increase the export of non-oil products, strengthen the domestic market and manage the availability of basic products; and to strengthen national distribution channels. To this end, it has identified ten priority products of key interest in its trade negotiations. Its economic priorities may also be understood within the context of various development plans, which aim to increase the competitiveness of Indonesia's businesses and encourage a shift into higher value-added activities. Central to this is the economic development of six regional economic corridors, each with industrial clusters focusing on priority sectors. These corridors would be connected through an enhanced transport and ICT infrastructure, which is currently poor. However, the realization of these objectives will be dependent to a considerable extent on private investment.

In 2009 the EU-Indonesia partnership and Cooperation Agreement (PCA) was signed. The PCA paved the way for closer cooperation in a wide range of fields and covers diverse areas of cooperation, such as trade, investment, human rights and climate change. The Agreement envisions four priority areas, namely education, human rights and democracy, trade and investment, and the environment (the Framework Agreement on Comprehensive Partnership and Cooperation 2009).

Indonesia and the EU have made significant strides in building a modern, outwardlooking partnership. This is rooted in thriving trade links, a shared attachment to advancing democracy and human rights, action on climate change and terrorism at home and abroad and expanding people-to-people links. There are five strategic interests at the heart of the relationship, i.e.: Indonesia is an emerging economic and commercial giant, a member of the G20 with sustained growth expected to reach $7 \%$ and an increasingly appealing climate for investors (the Framework Agreement on Comprehensive Partnership and Cooperation 2009).

The country enjoys a strategically attractive location where over half of world trade passes by its northern maritime border; ASEAN as powerhouse with $40 \%$ of the population and $35 \%$ of the economy. Indonesia is taking a natural lead in the bloc and is a crucial actor in the long term regional stability; Indonesia is the largest Muslim-majority country in the world. It is the most democratic country in the region with an increasingly positive human rights track record; Cooperation with Indonesia is crucial in order to tackle climate change. Indonesia is the $3^{\text {rd }}$ largest emitter of greenhouse gases and is a natural partner in finding global solutions; geostrategic and geopolitics of Indonesia as the busiest $3^{\text {rd }}$ trade route in Asia Pacific with Malacca Straits after Panama and Suez Canal (the Framework Agreement on Comprehensive Partnership and Cooperation 2009).

Thus, Indonesia and the EU have shared interests and commitment to develop closer collaboration is now encapsulated in the EU-Indonesia Partnership and Cooperation Agreement (PCA) which signed in November 2009 (Framework Agreement on Comprehensive Partnership and Cooperation 2009). The PCA paves the way for close cooperation in a wide range of fields, including trade, environment, energy, education, science and technology, migration and counterterrorism.

This cooperation has broadening and deepening through four strategies, i.e.: Efforts to boost trade flows, investment and market access, including through work towards an ambitious Comprehensive Economic Partnership Agreement (CEPA) covering trade, investment and services; A new EU-Indonesia Human Rights Dialogue launched in 2009 to intensify exchanges on questions of mutual interest; Enhanced people-to-people links, including through the Erasmus Mundus scholarship program, improved access by Indonesia to EU Research and Development opportunities and increased tourism; Development of intercultural exchange and engagement with moderate Islamic groups.

The substantial EU development cooperation program in Indonesia reinforces in 
furnishing support to: Indonesia's reform process in the areas of democratization, human rights, good governance; poverty reduction, including education; improvement of the trade and investment climate; tackling environmental problems and promoting ASEAN cooperation. The EU supported Indonesia in areas posing specific political challenges. The EU's contribution to the Aceh peace process illustrates the close ties between EU and Indonesia. The EU funded mediation talks and deployed the Aceh Monitoring Mission to oversee the implementation of the peace agreement and contributed nearly $€ 30$ million to help ensure the long-term stability of the peace process (Framework Agreement on Comprehensive Partnership and Cooperation 2009).

Economic and political dialogue between Indonesia and the EU takes the form of regular Senior Officials Meetings. As political relations are deepening, new structures for political engagement will be put in place once the PCA enters into force following ratification by EU Member States and Indonesia.

Trade relations in goods between the EU and Indonesia amounted to over $€ 25$ billion in 2015 with EU exports worth almost $€ 10$ billion and EU imports from Indonesia worth more than $€ 15$ billion, resulting in over $€ 5$ billion trade surplus for Indonesia. The EU is Indonesia's fourth largest trading partner. Indonesia's key exports to the EU include agricultural products, which amounted to $€ 4.3$ billion in 2015 . Other products exported by Indonesia are machinery and appliances, textiles and footwear, plastic and rubber products (the EU Delegation to Indonesia \& Brunei Darussalam 2016).

While, Indonesia is the EU's $5^{\text {th }}$ largest trading partner in Southeast Asia but ranks only $30^{\text {th }}$ in the general EU trade ranking. The EU exports to Indonesia mostly industrial products, including machinery and appliances, transport equipment and chemical products.

Total bilateral trade in services between the EU and Indonesia amounted to $€ 6$ billion in 2014 , with a surplus of $€ 2.2$ billion for the EU. The EU has a foreign direct investment stock in the country of nearly $€ 26$ billion, second only to Singapore (the EU Delegation to Indonesia \& Brunei Darussalam 2016).

The general EU-Indonesia relations are governed by the Partnership and Cooperation Agreement into force since May 2014. Indonesia also benefits from the EU's one-way customs duty discounts for developing countries under the standard Generalized Scheme of Preferences, GSP (Indonesia Ministry of Trade 2016).

Indonesia is one of ten member states of the Association of Southeast Asian Nations (ASEAN) and the $6^{\text {th }}$ one in the region to start negotiations for a bilateral Free Trade Agreement (FTA) with the EU, after Singapore (2010), Malaysia (2010), Vietnam (2012), Thailand (2013) and the Philippines (2015). To date, the EU has completed negotiations for bilateral agreements with two of them: Singapore (2014) and Vietnam (2015). Bilateral Free Trade Agreements between the EU and ASEAN countries will serve as building block towards a future EU-ASEAN agreement, which remains the EU's ultimate objective (the EU Delegation to Indonesia \& Brunei Darussalam 2016).

There are some reasons what Indonesia meant for the EU in challenging the dynamics of Southeast Asia economics development, i.e.: First, Indonesia is the largest dynamics economy in the Association of Southeast Asian Nations (ASEAN). It represents about 36\% of the region's GDP and has the largest population with 263 million inhabitants;

Second, bilateral trade in goods between the EU and Indonesia progressively amounted to $€ 25.3$ billion in 2015 , with EU exports worth $€ 10$ billion and EU imports worth $€ 15.4$ billion. The EU is Indonesia's $4^{\text {th }}$ partner. Indonesia is the $5^{\text {th }}$ EU partner in ASEAN and in the same year, it ranked $30^{\text {th }}$ in the overall EU trade worldwide;

Third, bilateral trade in services between EU and Indonesia in 2014 amounted to $€ 6$ billion in 2014, with the EU exports amounting to $€ 4.1$ billion and Indonesia's exports amounting to $€ 1.9$ billion. ASEAN, as a whole, ranks as the $8^{\text {th }}$ economy in the world and is the 
EU's $3^{\text {rd }}$ largest trading partner outside Europe, after the United States and China. Bilateral trade in goods and services between the EU and ASEAN reached $€ 246.5$ billion in 2015(the EU Delegation to Indonesia \& Brunei Darussalam 2016). Indonesia is the largest and most populated economy in ASEAN with +/- 36\% of ASEAN GDP. Indonesia is also one of the fastest growing economies in South East Asia with average GDP growth of 5.6\% in the past 10 years (20052015), and 5.07\% in 2017. While President Joko "Jokowi" Widodo has questioned the reasons behind Indonesia's sluggish growth despite receiving praise from various international organizations for its efforts to improve the economy (The Jakarta Post 2018).

The Southeast Asia region encompasses a number of countries that have experienced rapid dynamics economic growth in the last twenty years (Caballero-Anthony 2005). The region as a whole is wealthy in fossil energy sources. Energy demand in Southeast Asia is expected to increase dramatically in the coming years, creating problems in terms of relations among countries in the region and environmental degradation (Goldsmith 2007).

The fossil energy sources are not evenly distributed across the region, and consequently some countries are abundant in resources while others are poor in resources. This state of affairs means that some national conceptions about competition among countries in the region need to be overcome, and appropriate transnational infrastructure for oil and gas transportation needs to be developed. Intriguing opportunities may derive from the development of renewable energy for about six hundred thirty million people, 8.7 per cent of the entire world population.

\section{EU's Efforts in Southeast Asia}

In 2009, when proposing a European Council Decision on the conclusion of the Partnership and Cooperation Agreement between the EU and Indonesia (EU-Indonesia PCA), the European Commission put forward four major contributions the EU-Indonesia PCA would make: economic, political influence, values, and culture (the EU Delegation to Indonesia \& Brunei Darussalam 2016).

Economically, according to the European Commission, PCAs with member countries of the Association of the Southeast Asian Nations (ASEAN) would constitute prerequisite frameworks for negotiations of free trade agreements (FTAs). In terms of political influence, the European Union (EU) would be able to assume greater responsibility and exert greater influence in a region dominated by China and the United States (U.S). The Commission also suggested that the EU would be able to better promote European values and enhance concrete cooperation on matters of mutual interest. Finally, the EU-Indonesia PCA could be seen as an example of an inter-civilization partnership given that Indonesia is the world's democratic most populous Muslim country.

The EU's interest on Asia is longstanding. In 1977, following the establishment of the ASEAN, the EU, then, the European Economic Community, EEC, became one of the organization's first dialogue partners; this dialogue partnership was institutionalized through a formal Cooperation Agreement between the EU and ASEAN in 1980.

More recently, the EU has been negotiating PCAs with a number of ASEAN member countries. An FTA between the EU and Singapore has also been inked. The Northeast Asian countries Japan, China and South Korea are all EU strategic partners.

Moreover, the EU has already concluded an FTA with South Korea, and is negotiating an FTA with Japan. Regarding China, the EU and China are currently updating and upgrading the 1985 Cooperation Agreement, and the two sides have launched the negotiations for a stand-alone bilateral investment treaty (BIT). In addition, the Commission has published strategy papers addressing its relations with Asia, including Toward a New Asia Strategy, Europe and Asia: A Strategic Framework for Enhanced Partnerships, and A New Partnership with South East Asia 
(the EU Delegation to Indonesia \& Brunei Darussalam 2013).

In view of the EU's renewed interest in Asia and its high ambition to counterbalance the influence of China and the U.S in Southeast Asia as to explore whether existing policies are sufficient for the EU to achieve its goals. It argues that there is a mismatch between ambition and reality when the EU needs to strengthen its economic relations with Indonesia while at the same time aims to counterbalance China and the US influence in East Asia. This is especially evident when it comes to high politics. Further, in forging its trade relations with Asian countries, the EU is more a follower of the US than a counterbalancing power (Katzenstein 2005). The major role the EU plays in East Asia relates to the provisioning of humanitarian aid, which corresponds to its image of itself as a civilian power, improving soft power expansion.

During its partnership, the EU and ASEAN enjoy robust commercial relations. The EU is ASEAN's $3^{\text {rd }}$ largest trading partner, while ASEAN is the EU's $5^{\text {th }}$ largest trading partner. Total trade in 2011 in goods and services amounted to US\$265 billion. ASEAN had a surplus of US $\$ 25$ billion in its trade with the EU. The EU is the biggest provider of Foreign Direct Investment (FDI) into ASEAN, 24\% of the total (EU Commission 2012).

Significant Trade relation has increased over the past decades. EU exports to ASEAN were estimated at $€ 45.7$ billion in 1997, up from $€ 8.9$ billion in 1987. EU imports from ASEAN were valued at $€ 10$ billion in 1987 and had already surged to $€ 46$ billion by 1997(EU Commission 2012).

Initially, the structure of EU-ASEAN trade has undergone significant changes. In the past, EU exports to ASEAN have included a higher percentage of manufactured products. As ASEAN transforms from a commodity-producing region to a supplier of manufactured goods, there has been a dramatic shift in ASEAN's exports to the EU from primary products to manufactures. Hence, ASEAN's exports consisted mostly of raw materials such as wood, manioc, rubber and palm oil. Today, electronic equipment, textiles and clothing account for a larger share of exports (EU Commission 2012). Trade in services between the two regions has also grown in recent years.

Thus, in order to further improve trade between the two regions and to speed up ASEAN's economic integration, there is a regular dialogue at Ministerial level and ASEAN-EU Business Summits are held on a regular basis. The first ASEAN-EU Business Summit was organized in Jakarta in May 2011, followed by a second Business Summit in April 2012 in Phnom Penh and third one in Hanoi in March 2013. These meetings of business leaders, including small and medium-sized enterprises, with ASEAN Trade Ministers and the EU Trade Commissioner generate a host of recommendations for both parties to facilitate trade (the EU Delegation to Indonesia \& Brunei Darussalam 2013).

In 2007, the European Council authorized the European Commission to start negotiating a Free Trade Agreement (FTA) with ASEAN. FTA negotiations were launched at the ASEANEU Economic Ministers (AEM) Consultations held in Brunei Darussalam in 2007. However, trade talks were moving relatively slowly and eventually ground to a halt in

2009. The failed ASEAN-EU FTA paved the way for bilateral FTAs and negotiating Partnership and Cooperation Agreements (PCA) with individual ASEAN member states. The EU has concluded a Free Trade Agreement (FTA) with Singapore in 2012 and is negotiating FTAs with several other ASEAN countries (Vietnam, Thailand, and Malaysia). With Malaysia negotiations are well advanced. These agreements are stepping stones to an overarching regionto-region agreement between the EU and ASEAN (Lim 2012).

ASEAN exists and flourishes due to the European integration process adoption. ASEAN members have celebrated institutionalized cooperation as means to increase their international reputation. This diffusion process effectively provides a discount on the demand for a more formal institution. Since there was a lesser objective demand, institutionalized cooperation has taken the form or design of network governance geared toward the production of ASEAN as an 
institution, with little formalized structures and reliance on socially rather than legally binding rules. In sum, diffusion and networks explain ASEAN and given the EU's role model, the network structure and most importantly ASEAN's effectiveness in promoting regional stability.

For years, Asia has seen the emergence of a number of international institutions founded to further economic cooperation or international security. Two of the most important regional institutions are the Association of Southeast Asian Nations, established in 1967 by five Southeast Asian states (Indonesia, Malaysia, Thailand, the Philippines and Singapore) and successively extended to 10 Southeast Asian states in the 1990s, and the ASEAN Regional Forum, established in 1994 and comprising altogether 26 member states.

It's contradictory pattern of implantation failures and functionality have inspired theoretical explanations. It is ASEAN's and the ARF's "light" institutionalism that has drawn attention and split scholars on the question of whether ASEAN is really an ingeniously designed institution that delivers some peace with a flexible institutional structure, the ASEAN Way, (Acharya 2001; Johnston 1999) or whether it is an "illusionary community" that only distracts attention from the self-interested foreign policies of its members (Jones \& Smith 2002).

In January to April 2016, Indonesia's non-oil exports to EU countries reached US\$4.61 billion, or 11.33 percent of the total Indonesian non-oil exports to all countries in the world (Indonesia Ministry of Trade 2016). Meanwhile, non-oil imports during the same period amounted to US\$3.59 billion, or 9.59 percent of total non-oil imports Indonesia. The financial market concerns reflected only in the bid auction of government securities, which reached the target Rp17.53 trillion from Rp12 trillion or lower than the average weekly auctions translucent deals Rp25 trillion (Indonesia Ministry of Trade 2016).

Researcher argues in this article that ASEAN's record of inefficiency is an outcome of its nature as an institutional organization in a sociological institutional sense: ASEAN has, over its life-time, emulated the European integration process in key aspects. This has ASEAN states provided with legitimacy and reputation that has helped the organization and its members to survive as Third World states in an international system. The emulation of the European model, however, also accounts for its inefficiency: ASEAN states have decoupled their institutional structure from activities.

\section{Conclusion}

The coming free trade agreement in 2019 between Indonesia and the EU in the trade liberalization and foreign direct investment through comprehensive economic partnership agreement (CEPA) will bring benefits for regional economy development. It challenge Indonesia authorities and all stakeholders to concern for the improvement national infrastructure and logistics networks which aim to upgrade Indonesia economic growth through closer trade relations and attracting more incoming foreign investment from the EU countries.

However, Indonesia perceives that the asymmetry in the trade relationship with the EU being a much more important trade partner for the ASEAN countries than vice versa. In addition evidence of a general convergence in EU-ASEAN trade with intra-industry trade becoming ever more important than inter-industry trade and need significant quality differences.

Indonesia central and local authorities must focuses the changes in national development trade and investment strategy that accompanied by production diversification towards nontraditional manufacturing activities, and by liberalization of the regimes regarding inward investment. 
Furthermore these changes took place against the backdrop of a realignment of the major currencies in the beginning-2018s, and that companies from China, Japan, and South Korea were quick to use FDI to rationalize their economics activities throughout Asia. Still EU companies meanwhile were more concerned with the improving of the Single European Market (SEM) and with developments in Central and Eastern Europe. 


\section{REFERENCES}

\section{Books}

Acharya, Amitav. 2001. Constructing a Security Community in Southeast Asia. ASEAN and the Problem of regional order. London, New York: Routledge.

Aldrich, Howard E. 1979. Organizations and Environments. Englewood Cliffs, NJ: Prentice Hall, Inc.

Acharya, Amitav,ed. 2003. Asian Security Order. Instrumental and Normative Features. Stanford: Stanford University Press.

Balassa, Bela. 1964. Trade Prospects for Developing Countries. Homewood, IL: Richard D. Irwin, Inc.

Caballero-Anthony, Mely. 2005. Regional Security in Southeast Asia. Singapore: Institute of Southeast Asian Studies.

Chayes, Abram, and Antonia Handler Chayes. 1995. The New Sovereignty. Compliance with International Regulatory Agreements. Cambridge, MA: Harvard University Press.

Deyo, Frederic C., Richard F. Doner, and Eric Hershberg, eds. 2001. Economic Governance and the Challenge of Flexibility in East Asia. Lanham et al.: Rowman \& Littlefield Publishers, Inc.

DiMaggio, Paul J., and Walter M. Powell, eds. 1991. The New Institutionalism in Organizational Analysis. Chicago: The University of Chicago Press.

Dinan, Desmond. 2005. Ever Closer Union. An Introduction to European Integration. Boulder, London: Lynne Rienner Publishers.

Dosani, Rafic, Daniel C. Sneider, and Vikram Sood. 2010. Does South Asia Exist? Prospects for Regional Integration. New York: The Water H. Shorenstein Asia Pacific Research Centre.

Finnemore, Martha. 1996. National Interests in International Society. Ithaca: Cornell University Press.

French Pace, Elisabeth, Kathryn Young, Kathryn Rafferty, and Barbara K. Gordon. 1970. Regional Cooperation in Southeast Asia: The First Two Years of ASEAN 1967 - 1969. Study in The Guam Doctrine: Elements of Implementation. McLean, VA: Research Analysis Corporation.

Haas, Ernst B. 2004. The Uniting of Europe: Political, Social, and Economic forces, 19501957. Notre Dame, Ind.: University of Notre Dame Press.

Haacke, Jürgen. 2003. ASEAN's Diplomatic and Security Culture: Origins, Developments and Prospects. London, New York: Routledge.

Inglehart, Ronald, ed. 2003. Human Values and Social Change: Findings from the Values Surveys. Leiden, Boston: Brill.

Jackson, Robert. 1993. Quasi states: sovereignty, international relations and the Third World. Cambridge: Cambridge University Press.

Jones, David Martin, and Michael L.R. Smith. 2002. ASEAN's Imitation Community. Orbis (Winter):93-109.

Jorgensen-Dahl, Arnfinn. 1982. Regional Organization and Order in South-East Asia. London: MacMillan Press.

Katzenstein, Peter. 2005. A World of Regions. Asia and Europe in the American Imperium. Ithaca and London: Cornell University Press. 
Keohane, Robert. 1984. After Hegemony. Cooperation and Discord in the World Political Economy. Princeton: Princeton University Press.

Leifer, Michael. 1989. ASEAN and the Security of Southeast Asia. London.

March, James G., and Johan P. Olsen. 1989. Rediscovering Institutions. The Organizational Basis of Politics. New York: The Free Press.

Palmujoki, Eero. 2001. Regionalism and Globalism in Southeast Asia. New York, USA: Palgrave Macmillan.

Pierre, Jon, and B. Guy Peters. 2000. Governance, Politics and the State. New York: St. Martin's Press.

Research Information System (RIS). 2008. South Asia Development and Cooperation Report. New Delhi: Oxford University Press.

Strange, Roger, Jim Slater, and Corrado Molteni. 2000. The European Union and ASEAN: Trade and Investment Issues. New York, USA: St, Martin's Press.

Wendt, Alexander. 1999. Social Theory of International Politics. Cambridge, CB: Cambridge University Press.

Williamson, Oliver E. 1985. The Economic Institutions of Capitalism: Firms, Markets and Relational Contracting. London, UK: The Free Press, a Division of Macmillan, Inc. 1996. The Mechanisms of Governance. New York, Oxford: Oxford University Press.

\section{Chapter in Edited Books}

Acharya, Amitav. 1995. ASEAN and Asia-Pacific Multilateralism: Managing Regional Security. In New Challenges for ASEAN: Emerging Policy Issues, edited by A. Archarya and R. Stubbs. Vancouver: UBC Press.

Ahmad, Zakaria Haji. 2003. The structure of decision-making. In The 2nd ASEAN Reader, edited by S. Siddique and S. Kumar. Singapore: Institute of Southeast Asian Studies.

Alagappa, Muthiah. 2003. Institutional Framework. Recommendations for Change. In the $2^{\text {nd }}$ ASEAN Reader, edited by S. Siddique and S. Kumar. Singapore: Institute of Southeast Asian Studies.

Alburo, Florian A. 1992. The ASEAN Summit and ASEAN Economic Integration. In the ASEAN Reader, edited by K. S. Sandhu, S. Siddique, C. Jeshurun, A. Rajah, J. L. H. Tan and P. Thambipillai. Singapore: Institute of Southeast Asian Studies.

Cortell, Andrew P., and Susan Peterson. 2006. Dutiful agents, rogue actors, or both? Staffing, voting rules, and slack in the WHO and WTO. In Delegation and Agency in International Organizations, edited by D. G. Hawkins, D. A. Lake, D. L. Nielson and M. J. Tierney. Cambridge: Cambridge University Press.

Evans, Paul. 2005. Between Regionalism and Regionalization: Policy Networks and the Nascent East Asian Institutional Identity. In Remapping East Asia. The Construction of a Region, edited by T. J. Pempel. Ithaca and London: Cornell University Press.

Hill, Hal. 1992. Challenges in ASEAN Economic Co-operation. An Outsider's Perspective. In The ASEAN Reader, edited by K. S. Sandhu, S. Siddique, C. Jeshurun, A. Rajah, J. L. H. Tan and P. Thambipillai. Singapore: Institute of Southeast Asian Studies.

Job, Brian. 2003. Track 2 Diplomacy: Ideational Contribution to the Evolving Asian Security Order. In Asian Security Order. Instrumental and Normative Features, edited by M. Alagappa. Stanford: Stanford University Press.

Johnston, Alastair Iain. 1999. The myth of the ASEAN way? Explaining the evolution of the ASEAN regional forum. In Imperfect Unions. Security institutions over time and 
space, edited by H. Haftendorn, R. Keohane and C. Wallander. Oxford: Oxford University Press.

Khaw Guat Hoon. 1992. The Evolution of ASEAN, 1967-75. In The ASEAN Reader, edited by K. S. Sandhu, S. Siddique, C. Jeshurun, A. Rajah, J. L. H. Tan and P. Thambipillai. Singapore: Institute of Southeast Asian Studies.

Khoman, Thanat. 1992. ASEAN: Conception and Evolution. In The ASEAN Reader, edited by K. S. Sandhu, S. Siddique, C. Jeshurun, A. Rajah, J. L. H. Tan and P. Thambipillai. Singapore: Institute of Southeast Asian Studies.

Khong, Yuen-Foong, and Helen Nesadurai. 2007. Hanging Together, Institutional Design and Cooperation in Southeast Asia: AFTA and the ARF. In Crafting Cooperation: Regional International Institutions in Comparative Perspective, edited by A. Acharya and A. I. Johnston. Cambridge: Cambridge University Press.

Mayntz, Renate. 1993. Modernization and the Logic of Inter-organizational Networks. In Societal Change Between Market and Organization, edited by J. Childs, M. Crozier and R. Mayntz. Aldershot: Avebury.

Meyer,John W. 1987. The World Polity and the Authority of the Nation State. In International Structure: Constituting State, Society and the Individual, edited by G. M. Thomas, J. W. Meyer, F. O. Ramirez and J. Boli. London: Sage.

Pempel, T.J. 2005. Introduction: Emerging Webs of Regional Connectedness. In Remapping East Asia. The Construction of a Region, edited by T. J. Pempel. Ithaca and London: Cornell Univeristy Press.

Simon, Sheldon. 2006. Realism and Regionalism in Southeast Asia. The ARF and the war on terror. In Order and Security in Southeast Asia. Essays in memory of Michael Leifer, edited by C. J. Liow and R. Emmers. London, New York: Routledge.

Solingen, Etel. 2005. East Asian Regional Institutions: Characteristics, Sources, Distinctiveness. In Remapping East Asia. The Construction of a Region, edited by T. J. Pempel. Ithaca, London: Cornell University Press.

Wong, John. 2003. The ASEAN model of regional co-operation. In The $2^{\text {nd }}$ ASEAN reader, edited by S. Siddique and S. Kumar. Singapore: Institute of Southeast Asian Studies.

Wah, Chin Kin. 1992. The Institutional Structure. In The ASEAN Reader, edited by K. S. Sandhu, S. Siddique, C. Jeshurun, A. Rajah, J. L. H. Tan and P. Thambipillai. Singapore: Institute of Southeast Asian Studies.

Severino, Rodolfo. 2005. Framing the ASEAN Charter. An ISEAS Perspective. In Framing the ASEAN Charter. An ISEAS Perspective, edited by R. Severino: Institute of Southeast Asian Studies.

Powell, Walter W. 1990. Neither Market nor Hierarchy: Network Forms of Organization. In Research on Organizational Behavior, edited by B. Staw and L. Cummings. Greenwich, CT: JAI.

\section{Government Documents}

Badan Pusat Statistik Indonesia. (2015). Data Perdagangan. http://www.bps.go.id. Accessed on 28 December 2017.

Badan Pusat Statistik Indonesia (2017). Data Kependudukan. http://www.bps.go.id. Accessed on 29 December 2017. 
EU Commission. (2012). "ASEAN: EU Bilateral Trade and Trade with the World". DG Trade

Bilateral Statistics and Trade with the World.

http://trade.ec.europa.eu/doclib/docs/2006/september/tradoc_113471.pdf. Accessed on 21 December 2017.

Framework Agreement on Comprehensive Partnership and Cooperation between the European

Community and its Member States, of the one part, and the Republic of Indonesia, of the other part. 2009. Council of the European Union, Brussels, 21 October 2009.

Indonesia Ministry of Foreign Affairs. (2012). "Jakarta Declaration, Indonesia-Germany Joint Declaration for a Comprehensive Partnership: Shaping Globalisation and Sharing Responsibility, https://www.kemlu.go.id/Documents/Deklarasi/Jakarta\%20Declaration.pdf. Accessed on 27 December 2017.

Indonesia Ministry of Trade. (2016). "Dirjen PPI: Perundingan Pertama IEU CEPA Sangat Positif”. Siaran Pers Biro Hubungan Masyarakat. http://www.kemendag.go.id/id/news/2016/09/23/dirjen-ppi-perundingan-pertama-ieucepa-sangat-positif. Accessed on 20 December 2017.

\section{Internet Source}

Hermansyah, Anton. 2018. "Jokowi questions Indonesia's slow economic growth". The Jakarta Post 6 January 2018. http://www.thejakartapost.com/news/2018/01/06/jokowiquestions-indonesias-slow-economic-growth.html, accessed on 7 January 2018.

Manurung, Hendra. 2015. "Securing Southeast Asian Regional Security: Indonesia Diaspora". Proceeding of the International Seminar and Conference 2015: The Golden Triangle (Indonesia-India-Tiongkok) Interrelations in Religion, Science, Culture, and Economic. University of Wahid Hasyim, Semarang, Central Java $\begin{array}{llllll}\text { Indonesia } & \text { on } & 28 & \text { to } & 30 & \text { August }\end{array}$ https://publikasiilmiah.unwahas.ac.id/index.php/ISC/article/view/1269. Accessed on 10 January 2018.

Manurung, Hendra. 2016. "Indonesia \& Masyarakat Ekonomi ASEAN". The President Post Indonesia. June 2016.

http://thepresidentpostindonesia.com/wp-content/uploads/2016/06/The-PresidentPost-MEA-2016.pdf. Retrieved on 22 March 2017.

Manurung, Hendra. 2016. THE EFFECT OF BASUKI " AHOK " TJAHAYA PURNAMA LEADERSHIP STYLE ON INDONESIA DEMOCRACY (2012-2016). https://www.researchgate.net/publication/319717348_THE_EFFECT_OF_BASUKI_ AHOK_TJAHAYA_PURNAMA_LEADERSHIP_STYLE_ON_INDONESIA_DEM OCRACY_2012-2016, accessed on 10 January 2018.

Sekretariat Kabinet Republik Indonesia. 2015. Indonesia's Foreign Policy Priorities in 5 Years Ahead. http://setkab.go.id/en/indonesias-foreign-policy-priorities-in-5-yearsahead. Accessed on 8 January 2018. 
TPP or not, Vietnam will continue integration. 2016.

http://www.thejakartapost.com/seasia/2016/11/14/tpp-or-not-vietnam-willcontinue-integration.html. Accessed on 26 March 2017.

\section{Journals}

Acharya, Amivav. 2004. How Ideas Spread: Whose Norms Matter? Norm Localization and Institutional Change in Asian Regionalism. International Organization 58 (Spring):239-275.

. 2016. The Future of Global Governance. Global Governance 22 (2016), 453-460.

Ayoob, Mohammed. 1989. The Third World in the System of States: Acute Schizophrenia or Growing Pains? International Studies Quarterly 33:67-79.

Beeson, Mark. 2005. Rethinking Regionalism: Europe and East Asia in comparative historical perspective. Journal of European Public Policy 12 (6):969-985.

Börzel, Tanja A. 1998. Organizing Babylon - On the Different Conceptions of Policy Networks. Public Administration 76 (Summer):253-273.

Busse, Nikolas. 1999. Constructivism and Southeast Asian Security. The Pacific Review 12 (1).

Caballero-Anthony, Mely. 1998. Mechanisms of dispute settlement: The ASEAN Experience. Contemporary Southeast Asia 20 (1):38-65.

Chopparapu, Ramasaranya. 2005. The European Union. A Model for East Asia? Asia Europe Journal 3:133-136.

Collins, Alan. 2007. Forming a security community: lessons from ASEAN. International Relations of the Asia-Pacific 7 (2007):203-225.

Dobbin, Frank, Beth Simmons, and Geoffrey Garrett. 2007. The Global Diffusion of Public Policies: Social Construction, Coercion, Competition, or Learning? Annual Review of Sociology 33:449-472.

Fong, Tan Suan. 2005. European integration - A model for South-East Asia? Asia Europe Journal 3:7-11.

Haacke, Jürgen. 2003. ASEAN's diplomatic and security culture: A constructivist assessment. International Relations of the Asia-Pacific 3 (1):57-87.

Freistein, Katja. 2005. ASEAN after the Bali Summit (2003). From Paralysis to New Life? European Journal of East Asian Studies 4 (2):177-203.

Goldsmith, Benjamin. 2007. A Liberal Peace in Asia? Journal of Peace Research 44 (1):527.

Hafner-Burton, Emilie, and Kiyoteru Tsutsui. 2007. Justice Lost! The Failure of International Human Rights Law to Matter Where Needed Most. Journal of Peace Research 44 (4):407-425.

Haftel, Yoram. 2007. Designing for Peace: Regional Integration Arrangements, Institutional Variation, and Militarized Interstate Dispute. International Organization 61 (1):217237.

Higgot, Richard. 1994. Ideas, Identity and Policy Coordination in the Asia-Pacific. The Pacific Review 7:367-379.

Hoppe, Robert. 2002. Co-evolution of modes of governance and rationality: a diagnosis and research agenda. Administrative Theory \& Praxis 24 (4):763-780.

Huntington, Samuel P. 1971. The Change to Change. Modernization, Development, and Politics. Comparative Politics 3 (3):283-322.

Jones, Candace, William S. Hesterly, and Stephen P. Borgatti. 1997. A General Theory of Network Governance: Exchange Conditions and Social Mechanisms. Academy of 
Management Review 22 (4):911-945.

Jones, David Martin, and Michael L.R. Smith. 2007. Making Process, Not Progress. International Security 32 (1):148-184.

Kahler,Miles. 2000. Legalization as Strategy: The Asia-Pacific Case. International Organization 54 (3):549-571.

Katsumata, Hiro. 2006. Establishment of the ASEAN Regional Forum: constructing a 'talk shop' or a 'norm brewery'? The Pacific Review 19 (2):181-198.

Kawasaki, Tsuyoshi. 2006. Neither skepticism nor romanticism: the ASEAN Regional Forum as a solution for the Asia-Pacific Assurance Game. The Pacific Review 19 (2):219-237.

Khong, Yuen-Foong. 2005. The elusiveness of regional order: Leifer, the English school and Southeast Asia. The Pacific Review 18 (1):23-41.

Kivimäki, Timo Antero. 2001. The Long Peace of ASEAN. JPR 38 (1):5-25.

Koremenos, Barbara, Charles Lipson, and Duncan Snidal. 2001. The Rational Design of International Institutions. International Organization 55 (4):761-799.

Leifer, Michael. 1999. The ASEAN Peace Process: A Category Mistake. The Pacific Review $12(1): 25-38$.

Levy, Marc A., Oran R. Young, and Michael Zürn. 1995. The Study of International Regimes. European Journal of International Relations 1:3:267-330.

Lim, P. 2012. ASEAN's relations with the EU, Obstacles and Opportunities, in: EU External Affairs Review, July, 46-58.

Ravenhill, John. 2008. Fighting Irrelevance: An Economic Community "with ASEAN Characteristics". The Pacific Review (4).

Rüland, Jürgen. 2000. ASEAN and the Asian Crisis: theoretical implications and practical consequences for Southeast Asian regionalism. The Pacific Review 13 (3):421-451.

Meyer, John W., and Brian Rowan. 1977. Institutionalized Organizations. Formal Structure as Myth and Ceremony. American Journal of Sociology 83:340-363.

Mitzen, Jennifer. 2006. Ontological Security in World Politics: State Identity and the Security Dilemma. European Journal of International Relations 12 (3):341-370.

Nabers, Dirk. 2003. The social construction of international institutions: the case of ASEAN+3. International Relations of the Asia-Pacific 3:113-136.

Narine, Shaun. 2006. The English School and ASEAN. The Pacific Review 19 (2):199-218.

Nischalke, Tobias. 2002. Does ASEAN measure up? Post-Cold War diplomacy and the idea of regional community. The Pacific Review 15 (1):89-117.

Strang, David, and John D. Meyer. 1993. Institutional Conditions for Diffusion. Theory and Society 22:487-511.

Yuzawa, T. 2005. Japan's changing conception of the ASEAN Regional Forum: from an optimistic liberal to a pessimistic realist perspective. The Pacific Review 18 (4):463497.

Wendt, Alexander. 1992. Anarchy Is What States Make of It: The Social Construction of Power Politics. International Organization 46 (2):391-425.

Williamson, Oliver E. 1991. Comparative Economic Organization. Administrative Science Quarterly 36 (2):269-297.

Simmons, Beth, and Zachary Elkins. 2004. The Globalization of Liberalization: Policy Diffusion in the International Political Economy. International Organization 98 (1):171-189.

Stubbs, Richard. 2000. Signing on to liberalization: AFTA and the politics of regional economic cooperation. The Pacific Review 13 (2):297-318.

Podolny, Joel M., and Karen L. Page. 1998. Network Forms of Organization. American 
Review of Sociology 24:57-76.

\section{Newspaper articles}

Manurung, Hendra. 2016. "Brexit Impact on Indonesia Economy". The President Post Indonesia, 24 June 2016. 